\title{
20. Accommodating the Inuit majority: Traditional placenames in Nunavut today
}

\author{
Lynn Peplinski \\ Inuit Heritage Trust, Nunavut
}

For 4,000 years, Inuit and their predecessors have combed the almost 2 million square kilometres of the northern Canadian landscape, now known to the world as Nunavut, "Our Land". Evidence of extensive Inuit land use and occupancy is present in the more than 8,000 placenames that, lamentably, have yet to appear on official maps. While recognition of the Inuit home land came in 1993 with the signing of the Nunavut Land Claims Agreement, maps of the Arctic continue to reflect centuries of European exploration and discovery. The Inuit Heritage Trust has been documenting Inuit traditional placenames and has submitted close to 5,000 placenames to the Government of Nunavut to make them official since 2005, and estimate that more than 3,000 still need to be verified and processed. This paper grew out of a meeting with members of the Geographic Names Board of Canada who were assembled in Yellowknife, Northwest Territories in August 2007. Here, the author spoke with provincial and territorial representatives from across Canada about issues relating to aboriginal placenaming policies with particular attention to the use of non-aboriginal generics. Given that the Canadian Government's Principles and Procedures for Geographical Naming state that first priority shall be given to names with long-standing local usage by the general public, and Inuit comprise 85 per cent of the population in Nunavut, the time for Inuit names to appear on Canada's maps is overdue.

Twenty years after the signing of the Nunavut Land Claims Agreement, thousands of traditional placenames have been documented and submitted to the Government of Nunavut (GN) but have yet to appear on Canada's official maps. Traditional placenames clearly demonstrate the extent of Inuit land use and occupancy of the vast northern land that is Nunavut. Given the enduring presence of Inuit living in Nunavut, and the steady domestic and international interest in the potential of a northwest passage in Canada's north, there are many reasons why Inuit traditional placenames should see the light of day. 
While Canada is officially a bilingual nation with both English and French enjoying equal status, only 23 per cent of the population considers French as their mother tongue, and an overwhelming majority of francophones (18.5 per cent) are concentrated in one province, the province of Quebec. ${ }^{1}$

In Nunavut, a different version of bilingualism reigns with Inuktitut dominating French. Geographically isolated from the rest of Canada - its remoteness due to distance from and the lack of road infrastructure linking it to the rest of Canada, Nunavut has been home to Inuit and their predecessors for the past 4,000 years. Today, the territory boasts a population of about 32,000, 85 per cent of whom are Inuit, settled in 23 communities. ${ }^{2}$ There are arguably two Inuit languages in Nunavut. Inuktitut is spoken in all but two communities, where Inuinnaqtun is spoken. Each community is made up of speakers of one or more dialects depending upon where the family groups' ancestors lived on the land prior to moving into established communities around 50 years ago. There can be many dialects present in one community, again depending on where individual families resided on the land prior to moving into established settlements.

The year 2013 marks the 20th anniversary of the signing of the largest land claim in Canadian history, the Nunavut Land Claims Agreement (NLCA). Nunavut, formerly part of the Northwest Territories, covers just less than 2 million square kilometres occupying one fifth of Canada's land mass.

Created under the NLCA, the Inuit Heritage Trust exists to support an Inuit voice on issues relating to heritage including archaeology and placenames. With regards to traditional placenames, the Inuit Heritage Trust (IHT) organisation has two main goals:

1. The distribution, in communities, of traditional placenames knowledge on topographic, thematic maps.

2. Ensuring the traditional names are made official. This is also a land claim obligation for IHT (NLCA, Article 33 Part 9).

IHT's policy regarding naming features on maps is to capture the most appropriate dialect for the place where possible. That is, the dialects of descendants of family groups tied to specific geographical areas receive priority. Names for the same features, in other dialects may appear in the legend of the map. This effort is also explicitly noted on the individual map sheets produced by IHT.

\footnotetext{
1 Statistics Canada, 'Mother Tongue, Percentage Distribution for Both Sexes, for Canada, Provinces and Territories - 20\% Sample Data', http://www12.statcan.ca/english/census01/products/highlight/LanguageComposition/ Page. $\mathrm{cfm} ? \mathrm{Lang}=\mathrm{E} \& \mathrm{Geo}=\mathrm{PR} \& \mathrm{View}=1 \mathrm{a} \&$ Code $=0 \&$ Table $=2 \mathrm{a} \&$ StartRec $=1 \&$ Sort $=2 \& \mathrm{~B} 1=$ Distribution $\& \mathrm{~B} 2=$ Both (accessed 2 August 2007).

2 Statistics Canada, 'Number and distribution of the population reporting an Aboriginal identity and percentage of Aboriginal people in the population, Canada, provinces and territories, 2011', http://wwwl2. statcan.gc.ca/nhs-enm/2011/as-sa/99-011-x/2011001/tbl/tbl02-eng.cfm. (accessed 9 September 2013).
} 
Greenland, whose capital city of Nuuk is just two hours by air charter east of Iqaluit, Nunavut's capital city, has approached the dialect issue differently. Whereas in Nunavut, efforts are made to respect and record placenames in local dialects, in Greenland, the official language in all documentation including placenames is the Nuuk dialect of Inuktitut (language of the Inuit, also referred to as Greenlandic). Individuals in small communities are encouraged to speak their own dialects and maintain their own traditional placenames, but all written documentation, including placenames on maps, is in the Nuuk dialect. Also in Greenland, all names are written in roman orthography, a result of the Inuit language there having benefited from the written word more than 100 years earlier than its Canadian cousins. For these and other reasons, Greenlanders enjoy maps with their traditional Inuit names entirely in Greenlandic. ${ }^{3}$ Also worth pointing out is the disfavour with which Inuktitut names on maps are viewed by some non-Inuit. In a personal email from a staff person in a Danish Geodata Agency, Greenlandic maps were described as a "path of thorns for international users". ${ }^{4}$ Not everyone is impressed by the move to finally legitimise traditional indigenous names by putting them onto maps.

When compared with other indigenous populations in the world, Inuit of the eastern Arctic enjoy one of the highest percentages of native-language speakers: 64 per cent of the population in Nunavut can converse in Inuktitut or Inuinnaqtun. ${ }^{5}$ In the central and eastern arctic, the preferred orthography is still syllabics. This writing system was introduced by missionaries in the late 1800s to a people that had heretofore no written language. In a personal communication Kenn Harper, a local author and historian, recounted that when syllabics were introduced in the eastern arctic, people could learn the basic system in a couple of hours and then were expected to teach it to someone else. In this way the early system of syllabics swept through the eastern arctic. In a very short time after the introduction of syllabics, missionaries made Inuktitut reading materials available to Inuit in their own language. ${ }^{6}$

Though most young Nunavummiut (residents of Nunavut) in schools today learn English and use roman orthography, they also learn to write Inuktitut in syllabics. There is considerable debate about the advisability of maintaining two distinct writing systems, with some favouring abandoning syllabics for roman orthography; however, syllabics still appear to have strong support. In IHT's experience, Inuit in communities prefer to read Inuktitut placenames on

\footnotetext{
3 Pers. comm. with Carl Christian Olsen, Director Greenland Language Secretariat and Chair, Greenland Place Names Authority.

4 Private correspondence by email with an individual from the Danish Geodata Agency, 2007.

5 Statistics Canada, 'Aboriginal people and language', http://www12.statcan.gc.ca/nhs-enm/2011/as-sa/99011-x/99-011-x2011003_1-eng.cfm (accessed 13 December 2013).

6 Kenn Harper, author, historian and entrepreneur is a long-time resident of Iqaluit. He has researched and continues to write extensively about Inuit history, including weekly articles in the Nunatsiaq News.
} 
paper maps or in Google Earth, in syllabics. Thus the Inuit Heritage Trust is committed to producing maps with traditional placenames using syllabics. The Canadian Government, however, when it publishes maps for the wider public with the newly adopted traditional names, will transcribe the names in roman orthography. The volume of names, and the length of the names themselves may be problematic for government cartographers on a practical level. The syllabics characters combine consonant/vowel sounds (i, pi, ti, ki gi represented as syllabics) thus taking up less space on the map. A practical solution may be to limit the number of names on the maps, a standard practice in cartography but an unsatisfactory one for northern travellers. Typically the scale of a map dictates the amount of information that can be included. More placenames may be expected to be found on maps at larger scales such as 1:50,000 (of which there are 16 in an area covered by a 1:250,000 map). However, in IHT's experience, people prefer to see all the placenames information on 1:250,000 scale maps, with none omitted for the sake of a clean, uncluttered map. Given the vast distances hunters may cover in a day of travel by boat or snow machine, one reference map, rather than more than a dozen, is far more practical.

Draft topographic maps produced by IHT may contain hundreds of traditional placenames. One map $(1: 250,000)$ in particular, for an area of Cumberland Sound near Pangnirtung contains over 400 traditional placenames - a daunting challenge for the cartographer. ${ }^{7}$ If and when Inuit traditional placenames become official, will the Canadian Government be able to demonstrate them satisfactorily on maps? Unfortunately, IHT only has resources enough to produce a small selection of maps that are shared with communities. Though at the federal level there is currently a small group of individuals in the Mapping Information Branch that has been trying to promote interest in a program to produce "Canadian Arctic Prototype Maps - Customized, Multilingual, Topographic", they have been unsuccessful due to reduced budgets. ${ }^{8}$

Concern exists that if not added to current maps, traditional names will become a relic of a way of life only 50 years ago - a way of life which has been rapidly and even traumatically replaced by modernity. However, the land has not changed and neither has the need to know and understand the land, if not for one's absolute survival, then for Inuit to retain a sense of themselves and their culture. Traditional placenames allow today's Inuit to maintain an appreciation and an intimate connection to the land, similar to that of their predecessors. By way of

7 Map 26J is the map with the greatest number of traditional, but still unofficial placenames (as of 09/2013) in Nunavut. This map was made by the Canada-Nunavut Geoscience Office in partnership with IHT and may be accessed online at (with instructions): http://geoscan.ess.nrcan.gc.ca/cgibin/starfinder/0?path=geoscan.fl \&id=fastlink \&pass $=\&$ search $=$ R\%3D288016\&format=FLFULL Click on GeoPub: Free download (zip 42577 $\mathrm{kB}$ ) near the top of the page; page 2) choose 'Download this publication'; page 3) enter email and Accept Agreement; page 4) right click on the browser link and do 'Save Target A'.

8 Pers. comm. with Eva Siekierska of the Mapping Information Branch, Earth Sciences Sector, National Resources Canada. 
example, in the summer of 2007, a group of hunters attempted to trap beluga whales in an inlet on the descending tide by throwing rocks into the water to keep the belugas in, trapping them behind a sand bar. The inlet, Millorialik, "where you throw something", is named for this activity. Despite the hunters' efforts, the beluga managed to escape. The hunters left the area disappointed but with a renewed sense of the challenge experienced by their predecessors to survive on the land. ${ }^{9}$ Formerly for Inuit, the animals meant everything: food, shelter, tools, transportation. Besides a few wild roots and berries, there was no other option for sustaining life in this harsh northern country. Though modernity has meant a move to settlements, heated homes and the availability of store-bought food, hunting remains a necessary cultural activity to put food on the table. A study exploring the issue of food security in Nunavut found that relying exclusively on market food is an unaffordable option for many families (Chan et al. 2006: 416-431). Traditional placenames not only offer insight into past land use but practical information for the modern hunter.

Nunavut is still a relatively new territory and the population small. There are fewer than a handful of individuals working on placenames issues on a regular basis. Therefore, progress to make traditional placenames official is slow. In 2009, IHT submitted 11 maps to the Government of Nunavut containing approximately 900 traditional placenames. Two of these maps (with a total of 290 names) have gone through the GN system and may be official as of 2014. Since 2011 an additional 4,000 were submitted to the GN to be made official. There still remain thousands of names that need to find their way onto official maps.

\section{Generics}

The issue of generics and how these are handled across jurisdictions varies. There are a relative few traditional placenames currently dotting Nunavut's maps, the ones placed there when the territory was part of the Northwest Territories and prior to a made-in-Nunavut Toponymy Policy. However, all of these names are accompanied by English generics. For example, Qikiqtarjuaq Island and Tasiujarjuaq Lake are both very common names meaning Big (-juaq) Island (Qikiq-) and Big (-juaq) Lake (Tasi-), making the added English "Lake" or "Island" generics redundant. Examples of this tautology are also very common for maps in northern Quebec.

The province of Quebec, located south of Nunavut has more than 7 million inhabitants with more than 80 per cent claiming French as their first language. ${ }^{10}$

9 My colleague at the Inuit Heritage Trust, Sheila Oolayou, spoke directly with hunters from the group, 2007.

10 Statistics Canada, 'Table 11', http://www12.statcan.ca/census-recensement/2006/as-sa/97-555/table/t11eng.cfm (accessed 20 July 2007). 
However, the northern third of the province, a region known as Nunavik, is sparsely populated with about 10,000 Inuit living in 14 communities scattered along the coast. Here Inuktitut is the first language of over 90 per cent of the Inuit population according to the Avataq Cultural Institute. ${ }^{11}$ In everyday communications, therefore, English and French take a back seat to Inuktitut in the lives of the people who have lived in this northern land for centuries. In a sense, Nunavik is a nation within a nation, geographically isolated from the more densely populated part of the province, as Quebec is also a unique nation within the larger Canada because of its culture, language and set of laws (Sheppard 2006).

In Canada, Inuit distinguish themselves from other First Nations groups. That is, Inuit do not fall under the general umbrella of First Nations; they remain their own distinct group. In Quebec, as in most of the provinces and territories in Canada, aboriginal (First Nations peoples including Inuit) make up 8.1 per cent of the province's population, with some First Nations living on reserves, some not. ${ }^{12}$

On the Nunavik (Quebec) maps much effort was undertaken to document almost 8,000 traditional Inuit names which were eventually published in an Avataq Cultural Institute gazetteer in $1987 .{ }^{13}$ However, those traditional names were altered by the Commission Toponymique du Quebec when they were made official, by the addition of French generics. With regards to generics, the Quebec Toponymy Policy (adopted in 1987 and revised in 1990) states that:

Aboriginal place names that contain a generic (attached to or separate from the specific) in their language of origin are assigned a generic in French when they are officialized. This French generic represents the best possible translation of the Aboriginal term.

The separate Aboriginal generic is not included in the official name, unless it constitutes the sole element of the original place name. To counter the often negative reaction to the Aboriginal place names that are considered too long and difficult to pronounce or remember, the Commission may officialize shortened versions of inventoried names provided their meaning is not lost as a result.

11 Avataq Cultural Institute, 'Inuktitut Language Program', http://www.avataq.qc.ca/programs/language_ en.cfm (accessed 20 July 2007).

12 Statistics Canada, 'Aboriginal peoples of Canada: A demographic profile', Statistics Canada 2001 Census: analysis series, http://www12.statcan.ca/english/census01/Products/Analytic/companion/abor/ pdf/96F0030XIE2001007.pdf (accessed 15 July 2007). Page 23.

13 Avataq Cultural Institute, 'Nunatop: Inuit place names', http://www.avataq.qc.ca/en/Institute/Departments/ Research-Library-and-Archives/Place-names/Nunatop-Inuit-place-names. (accessed 9 September 2013). 
When an Aboriginal place name does not include a generic in its original form, the Commission, in officializing the name, will add a French generic if and when this type of place name is usually expressed with a generic in French. ${ }^{14}$

One could argue that adding French generics makes placenames more accessible to the "whole" Quebec community. However, the "whole" by large majority, in this particular region of Quebec consider Inuktitut to be their first language. The added French generic effectively changes the name. Also, if you are a native speaker the name/generic combination becomes almost farcical because of the tautology.

Given the geographical isolation of many Inuit communities from the more densely populated parts of Canada and the intense role the land plays in everyone's lives, in addition to the language reality, Inuit and the wider public may be better served by the publication of a glossary of Inuktitut placenames. Such a glossary would provide insight into the language and the world view present in the traditional naming system of Inuit in northern Canada rather than adding a generic to satisfy the French/English speaking minority.

Kearns and Berg (2002) discuss the issue of placenames as a form of resistance and contend that resistance to naming can occur on at least two levels: the creation and deployment of alternate names and the use of alternative pronunciations for established names. By its policy to replace aboriginal placename generics with French ones, or to add generics to aboriginal names, is the Quebec Government, through its Toponymy Policy, resisting efforts by Inuit wishing their own names to be legitimised? This exercise has its roots in Quebec's Charter of the French Language, safeguarding French, in Quebec, as the dominant language.

Quebec is an interesting case because it is the largest province in Canada in area (the three northern territories do not count as provinces) and the second largest in population. As a primarily French-speaking province, Quebec has fought long and hard against the cultural domination of the English majority in Canada. By introducing Bill 101, the Charter of the French Language, the government has sought to protect the language and to ensure the province's status and future as a French-speaking nation. All signage, commercial advertising, street signs and services, as well as placenames generics, are in French. As has been noted though, fully a third of Quebec's land mass is understood to be Inuit territory, where a version of a self rule accord looms. Criticism of Quebec's Charter of the French Language has been widespread, considered by some to be an infringement on their rights and freedom to work, be educated or read or post signage in their

14 Commission de Toponymie Québec, ‘Politiques de la Commission de toponymie (1990)', http://www. toponymie.gouv.qc.ca/ct/toponymie_expliquee/politiques_topo.html (accessed 20 May 2007). 
language of choice, most often English. However, 30 years after its introduction Bill 101 has been reported as being relatively well accepted in the province (Bauch 2007).

According to Danielle Turcotte, Director, Commission de toponymie, the Quebec Government is currently seeking a way to publish on the web both the official placenames as well as the unofficial aboriginal placenames in a way that will underline the official status of names while also providing visibility for the purposes of conservation of the aboriginal placenames in the memories of aboriginal communities. ${ }^{15}$

For Nunavummiut to insist on their traditional names becoming official is a logical, natural follow up to the Nunavut Land Claims Agreement. Kearns and Berg (2002) also note that:

Place names are publicly pronounced, [and] there is thus scope to not only identify a point on the map, but also to make a point through (metaphorically) mapping out one's politics of place in speech. (Kearns and Berg 2002: 287)

Indeed, the Nunavut Land Claims Agreement is the largest in Canadian history. Nunavut is not Nunavut Territory, it is Nunavut (without the added generic); translated as Our Land, the name is a significant statement when one locates this massive territory on a map. Accordingly, all traditional placenames are expected to be accepted as is, without the addition of English generics. There is an exception to this rule, however. The Geographic Names Board of Canada maintains a list of names of pan-Canadian significance. The names on this list of prominent geographical features are to appear in all official documentation with English and French names only. This may not be hugely problematic given that many of the more prominent geographical features identified as having panCanadian significance do not have traditional names. For example, Inuit tended not to name large features that extended for hundreds of kilometres (Frobisher Bay or the whole of Cumberland Sound or Baffin Island). There are exceptions however, as in the case of seven First Nations groups in the Northwest Territories, each traditionally having their own name to the Mackenzie River, a significant river in Canada's north-west. ${ }^{16}$

As noted earlier in this chapter, a staff member from the Danish Geodata Agency referred to Greenlandic placenames as a path of thorns. While Greenlandic names on maps and charts may be difficult to pronounce, so are many foreign names to the uninitiated anywhere. However, those Greenlandic names are also a pronouncement; they make a strong statement about the Inuit presence on the

15 Pers. comm. with Danielle Turcotte, Commission de toponymie du Quebec, by email, 2007.

16 Pers. comm. with Tom Andrews, Government of the Northwest Territories, Cultural Places Program, 2007. 
islands and in the fiords of Kalallit Nunaat (Greenland). Also worth pointing out is that English or French or Danish names, as in the Greenland example, are equally difficult for native Inuktitut speakers to pronounce. Despite the fact that there are maps with official English toponyms in Nunavut, Inuit continue to refer to places on the land using traditional Inuktitut names, which to them, are far more informative, and easier to pronounce in their own language. Finally, as stated in the Canadian Government's Principles and Procedures for Geographical Naming 2011, Principle 2:

First priority shall be given to names with long-standing local usage by the general public. Unless there are good reasons to the contrary, this principle should prevail.

Consider the following passage by Canadian author Peter Steele, in his book, The Man who Mapped the Arctic:

The chaps in this narrative were much exercised about maps. Mapping was why they were there. The indigenous peoples appear to have given few names to prominent geographical features, certainly not the plethora that sprang from visits by Europeans. Franklin, Back, and other explorers could, and did, walk in and map a continent. Then by way of recognizing their patrons and sponsors these first "white men" sprinkled the maps they drew with the names of luminaries, major and minor, who are now recorded in perpetuity to the total denial of the native culture. (Steele 2003: xx)

(As a northerner himself, Steele apparently had little awareness of the extent of traditional aboriginal placenames that existed prior to these "others" entering the scene.)

The type and scale of features named on maps gives insight into many aspects of the Inuit presence on the land. The explorers and other adventurers who bestowed their names on the coastal areas often did so from the decks of their relatively large ships. With these they also travelled faster than did Inuit in their small qajait (kayaks) in summer or fall, or by dog team or on foot in winter. There are many examples where names of large inlets and other bodies of water do not have Inuktitut counterparts to the "colonial" ones on the maps. However, the more discrete features within those larger bodies do have traditional names. For example, only the end of Frobisher Bay is named Tasiujarjuaq (like a big lake); the name represents almost a third of the whole named bay that is hemmed in by islands, but not the whole bay.

A working paper prepared for a 2004 meeting of the United Nations Group of Experts on Geographical Names describing Canadian activities with respect to indigenous names shows an evolution in the practice of accepting indigenous 
names into official nomenclature. ${ }^{17}$ In this paper, $\mathrm{O}^{\prime}$ Brien notes that at one time names that were deemed cumbersome and unpronounceable were shortened or rejected and that, in recent years, the provincial and territorial names boards have been more open to the approval of names with long specifics. Both examples of long names (one had 31 letters) still had English and French generics attached to them. However, the author does note further in the document that geographical names usually include both a specific and a generic and that the generic term will be in English, French, or in an aboriginal language.

Beyond Quebec, a look at the treatment of generics and placenames in other Canadian provinces and territories and the United States follows.

\section{Moving from west to east across Canada ${ }^{18}$}

Janet Mason, Provincial Toponymist in British Columbia (BC), related that as part of the Nisga'a Treaty signed in 1999, 40 traditional placenames were adopted into legislation. However, despite there being intensive native language programs in schools since this time, these names, entirely in the Nisga'a language, are not in local use, suggesting a disconnect between the older and younger generations. British Columbia's Toponymy Policy, available on the internet, states that placenames will be accepted in a single language form; however, despite this statement, aboriginal names with English generics are accepted if this is how the names are used locally. ${ }^{19}$ Mason, emphasised that, in her opinion, maps are not a tool for language retention. This comment contrasts with the Nunavut experience where, in the Inuit Heritage Trust's experience, maps with Inuktitut placenames (as opposed to the more widely available topographic maps with primarily English-only toponyms) are actively sought by hunters who tend to communicate with each other over short wave radio in Inuktitut while "on the land".

In Alberta, local use dictates the form of the name confirming that English generics are not automatically added as a matter of course. ${ }^{20}$

17 United Nations Group of Experts on Geographical Names, 'Standardization in Multilingual Area; Some Canadian Activities with Respect to Indigenous Names', Twenty-second Session New York, 20-29 April 2001. Working Paper No.15 (A) Item 18 of the Provisional Agenda, http://unstats.un.org/unsd/geoinfo/UNGEGN/ docs/22-GEGN-Docs/wp/gegn22wp15a.pdf.

18 I attended a Geographic Names Board of Canada meeting in Yellowknife, Northwest Territories in August 2007 where I was able to ask provincial and territorial representatives about issues relating to the treatment of generics in their jurisdictions.

19 Geographical Names Office, ‘British Columbia's Geographical Naming Principles: Geographical Naming Policy and Procedures', http://geobc.gov.bc.ca/bcnames/files/GeogNamingPolicy.pdf.

20 Geographical Names Manual. Government of Alberta Historic Resources Management Geographical Names Program. See pages 12-12 for Principle 5(B) Names in Languages other than English and Principle6 (B) Form and Character of Aboriginal Names. http://culture.alberta.ca/heritage/resourcemanagement/ archaeologyhistory/geographical/pdf/2012/alberta_geographical_names_manual_12.pdf. 
Alberta's example is unlike its neighbour to the east, Saskatchewan, which though it describes itself as "aligned with the Geographic Names Board of Canada", has a similar policy to that of Quebec. That is, the English generic is always attached to the aboriginal name. If a generic is integral to the name, an English generic would be added. If the generic is separate from the specific, the aboriginal generic might be dropped. Here, the provincial names authority indicated that there is interest in capturing the aboriginal names and their meanings but these would appear in a database and not in the official road signs or other documentation.

Manitoba's policy is similar to that of Saskatchewan and Quebec in that placenames always are given an English generic. One exception was noted that of a populated place known by the aboriginal name "Manitou" with no generic. Incidentally, Manitoba is also a province with an outspoken Frenchspeaking minority.

Ontario, the most populous province, home to almost 40 per cent of the Canadian population has a relatively small First Nations population (less than 2 per cent of the total population). ${ }^{21}$

Ontario accepts aboriginal generics, as in the case of a recent aboriginal name that was approved in Ontario: Miskwaa Ziibi where the entity type is listed as River, and the generic in the name itself "Ziibi" means "River". Therefore the name - Miskwaa Ziibi-stands on its own without an English or French generic in the name itself. ${ }^{22}$

The Nova Scotia placenames policy stipulates that names should be adopted in a single language form; this includes a provision allowing the generic term to be recorded in an aboriginal language. ${ }^{23}$

New Brunswick, in many ways, is just getting started with its Toponymy Office. As in some of the other provinces names changes are not encouraged. However, First Nation peoples on reserves in the province may apply to the federal department of Indian and Northern Affairs with a proposal for a new name, a process in place in all the provinces. New placenames proposals with demonstrated support and little or no conflict have a better chance of being accepted.

In Newfoundland, the Geographical Names Board Act, states that the Inuit Central Government is the final authority on the spelling and pronunciation of

\footnotetext{
21 Pers. comm. with Carl Christian Olsen, Director Greenland Language Secretariat and Chair, Greenland Place Names Authority.

22 Ontario Geographic Names Board, 'Principles of Geographic Naming', http://www.mnr.gov.on.ca/ stdprodconsume/groups/lr/@mnr/@geographicnames/documents/document/stel02_207469.pdf.

23 Nova Scotia Government, 'The Naming Process: Guiding Principles', https://www.gov.ns.ca/snsmr/ placenames/namingprocess.asp (accessed 31 August 2007).
} 
Inuktitut placenames in the province. The Inuit of Nunatsiavut, a land claim settlement area within the province of Newfoundland and Labrador, number about 5,500 persons. The actual area covered in the Labrador Inuit Land Claims Agreement, consists of 28,000 square miles $\left(72,520 \mathrm{~km}^{2}\right)$ of land in Labrador and 17,000 square miles $\left(44,030 \mathrm{~km}^{2}\right)$ of sea. Labrador Inuit do not own this land, but have special rights related to traditional land use.

With regards to placenames, the Nunatsiavut Land Claim Agreement ${ }^{24}$ states that the Nunatsiavut Government will have the exclusive right to establish official placenames in Labrador Inuit Lands, subject to approval by the responsible provincial minister. The Government of Newfoundland and Labrador must consult the Nunatsiavut Government on any proposed placenames in the Settlement Area outside Labrador Inuit Lands. ${ }^{25}$

In the Yukon, one of Canada's three northern territories, aboriginal names stand on their own. There are special challenges here as there may be as many as four First Nations groups that claim a particular area and therefore a feature might have four aboriginal names, with the addition perhaps of a fifth nonaboriginal name. The Yukon Government has a unique format to handle some of the overlapping First Nations names through a Land Claims Umbrella Final Agreement (UFA) in which Alternate Placenames are recognised by Canada, but do not show up on maps and road signs. Worthy of note is that as of 2003, the official name of Yukon Territory was changed to Yukon, dropping the generic.

The situation in the Northwest Territories is similar to that of the Yukon but here the Government of the Northwest Territories insists that as many as seven aboriginal names for one feature, the Mackenzie River is a prime example, be accepted and that Ottawa (the seat of the federal government) must figure out a way to make this work. This act is also in conflict with a United Nations principle of univocity, one name for one place. A First Nations leader, guest at a Geographic Names Board of Canada meeting in Yellowknife in August 2007, also expressed that, in naming, the contributions of white pioneers in Canada's north should not be forgotten. He noted that the traditional names must appear but the other non-traditional names are also an important part of history.

In terms of trends in toponymy in Canada, a working group of the Geographical Names Board of Canada presented a report on Proposed Delineation Guidelines at its annual members meeting in August 2007. In this report they noted how toponymic and topologic perspectives do not necessarily agree and that an important distinction must be made between the application of a geographical

24 Government of Newfoundland and Labrador, 'Nunatsiavut Land Claims Agreement' http://www.laa.gov. nl.ca/laa/claimsaip/Aipchp16.htm (accessed 2 August 2007).

25 Nunatsiavut Government, 'Highlights of the Labrador Inuit Land Claims Agreement', http://www. nunatsiavut.com/en/lilca_highlights.php (accessed 2 August 2007). 
name based on local usage and the physical extent of a feature. The example given is of a hydrologist defining a river based on its physical measurements of its source, length and flow. Local citizens, however, may apply the name to only a portion of this physical feature. These Delineation Guidelines will be of assistance to the Inuit Heritage Trust as we struggle to translate the Inuit concept of a named place to an "acceptable" generic in English when there is not a perfect fit between language, cultures and world views. When we submit placenames to the Government for them to be made official, we normally also submit an electronic map with shape files with named areas delineated. These new Delineation Guidelines reflect the reality that we are working in.

Finally, a glance in the direction of the Principles, Policies, and Procedures: Domestic Geographic Names (2003) for the United States as a whole (as opposed to state by state).

The United States Board on Geographic Names (USBGN) does not encourage changes in official geographic names. However, the USBGN supports the expert documentation of geographic names derived from Native American languages. The USBGN recommends the use of generic terms with names derived from Native American languages that are easily understood by the general public and are common to the areas in which the names are applied. This policy applies even though the Native American names may already contain generic elements. This being said, Louis Yost of the USBGN did express that the Board will consider applications with no generics. Though it highly recommends English generics, the USBGN has been asked by native groups to consider names as they are used locally. ${ }^{26}$

\section{Summarising approaches to generics with aboriginal placenames in Canada}

The position of the national authority, the Geographic Names Board of Canada is that placenames generics can be in English, French or in an aboriginal language. However, the provinces and territories have the authority for naming decisions within their jurisdictions and the GNBC follows the lead of these jurisdictions. In provinces and territories where there is either a large and/or outspoken First Nations or Inuit presence, naming authorities are accepting traditional placenames as they are used locally, without English or French generics, into

26 As noted in footnote xiv. Also United States Board on Geographic Names, http://geonames.usgs.gov/ pppdgn.html\#3-J. 
official nomenclature. Three exceptions are Manitoba, Saskatchewan and Quebec, though these three appear to be willing to accord visibility to the aboriginal names without going all the way to accepting the names as official.

Quebec has been making efforts to grant visibility to aboriginal placenames in their original forms for the benefit of aboriginal communities. At a meeting of the Geographic Names Board of Canada (GNBC) in August 2007, the Director of the Quebec Commission de toponymie, in a teleconference, mentioned to the assembled group that her office had a received a proposal for 900 aboriginal placenames. She wondered openly if anyone else in the country was dealing with similar volumes of names changes and new names. In fact Nunavut is leading the country with proposals for thousands of placenames to be made official.

In the rest of the country, and particularly where First Nations and Inuit populations are in the majority, such as in the territories north of the $60^{\text {th }}$ parallel, the trend is towards reverting to aboriginal placenames and ensuring that the integrity of these names is not marred by the addition of English and French generics and that the names stand as they are in use by local populations.

\section{References}

Avataq Cultural Institute, 'Inuktitut Language Program' http://www.avataq. qc.ca/programs/language_en.cfm (accessed 20 July 2007).

-, 'Nunatop: Inuit place names', http://www.avataq.qc.ca/en/Institute/ Departments/Research-Library-and-Archives/Place-names/Nunatop-Inuitplace-names (accessed 9 September 2013).

Bauch, H. 2007, Language law widely accepted after 30 years: Quebec's Bill 101 engendered new era of social peace. http://www.canada.com (accessed 26 August 2007).

Chan, H.M., K. Fediuk, S. Hamilton, L. Rostas, A. Caughey, H. Kuhnlein, G. Egeland and E. Loring 2006, 'Food security in Nunavut, Canada: barriers and recommendations', International Journal of Circumpolar Health 65(5): 416-431.

Commission de Toponymie Québec, 'Politiques de la Commission de toponymie (1990)', http://www.toponymie.gouv.qc.ca/ct/toponymie_expliquee/politiques_ topo.html (accessed 20 May 2007).

Department of Culture, Language, Elders and Youth, Government of Nunavut, http://www.gov.nu.ca/cley/ (accessed 15 August 2007). 
Geographical Names Office, ‘British Columbia's Geographical Naming Principles: Geographical Naming Policy and Procedures', http:/geobc.gov.bc.ca/ bcnames/files/GeogNamingPolicy.pdf.

Government of Manitoba, 'Manitoba Geographical Names Program', http:// www.gov.mb.ca/conservation/geomatics/geo_names/index.html.

Government of Newfoundland and Labrador, 'Labrador Inuit Land Claims Agreement in Principle,Chapter 16: Place Names', http:/www.laa.gov.nl.ca/ laa/claimsaip/Aipchp16.htm (accessed 2 August 2007).

Kearns, R.A. and L.D. Berg 2002, 'Proclaiming place: towards a geography of place name pronunciation', Social and Cultural Geography 3(3): 283-302.

Nova Scotia Government, 'The Naming Process: Guiding Principles', https://www. gov.ns.ca/snsmr/placenames/namingprocess.asp (accessed 31 August 2007).

Nunatsiavut Government, 'Highlights of the Labrador Inuit Land Claims Agreement', http://www.nunatsiavut.com/en/lilca_highlights.php (accessed 2 August 2007).

Ontario Geographic Names Board, 'Principles of Geographic Naming', http:// www.mnr.gov.on.ca/stdprodconsume/groups/lr/@mnr/@geographicnames/ documents/document/stel02_207469.pdf.

Sheppard, R. 2006, 'Quebec nationalism, a long history', CBC News, http:// www.cbc.ca/news/background/parliament39/quebecnation-history.html (accessed 31 August 2007).

Statistics Canada, 'Aboriginal people and language', http://wwwl2.statcan. gc.ca/nhs-enm/2011/as-sa/99-011-x/99-011-x2011003_1-eng.cfm (accessed 13 December 2013).

- 'Aboriginal peoples of Canada: A demographic profile: 2001 Census: analysis series', January 2003, http://www12.statcan.ca/english/census01/Products/ Analytic/companion/abor/pdf/96F0030XIE2001007.pdf (accessed 15 July 2007).

-, 'Mother Tongue, Percentage Distribution for Both Sexes, for Canada, Provinces and Territories - 20\% Sample Data', http://www12.statcan.ca/ english/census01/products/highlight/LanguageComposition/Page.cfm?Lang $=\mathrm{E} \& \mathrm{Geo}=\mathrm{PR} \& \mathrm{View}=1 \mathrm{a} \&$ Code $=0 \&$ Table $=2 \mathrm{a} \&$ StartRec $=1 \&$ Sort $=2 \& \mathrm{~B} 1=$ Dist ribution \&B2=Both (accessed 2 August 2007).

—, 'Number and distribution of the population reporting an Aboriginal identity and percentage of Aboriginal people in the population, Canada, provinces and territories, 2011', http://www12.statcan.gc.ca/nhs-enm/2011/as-sa/99011-x/2011001/tbl/tbl02-eng.cfm. (accessed 9 September 2013). 
—, 'Table 11', http://www12.statcan.ca/census-recensement/2006/as-sa/97-555/ table/t11-eng.cfm (accessed 20 July 2007).

Steele, P. 2003, The Man Who Mapped the Arctic: The Intrepid Life of George Back, Franklin's Lieutenant. Raincoast Books, Vancouver, British Columbia.

United Nations Group of Experts on Geographical Names, 'Standardization in Multilingual Area; Some Canadian Activities with Respect to Indigenous Names', Twenty-second Session New York, 20-29 April 2001. Working Paper No.15 (A) Item 18 of the Provisional Agenda, http://unstats.un.org/unsd/geoinfo/ UNGEGN/docs/22-GEGN-Docs/wp/gegn22wp15a.pdf (accessed 3 June 2007).

United States Board on Geographic Names, 'Policy X: Names of Native American Origin from United States Geological Survey: Principles, Policies, and Procedures: Domestic Geographic Names', Geographic Names Information System website, Online Edition (revised), 2003, http://geonames.usgs.gov/ pppdgn.html\#3-J (accessed 3 June 2007). 
This text taken from Indigenous and Minority Placenames: Australian and International Perspectives, Edited by Ian D. Clark, Luise Hercus and Laura Kostanski, published 2014 by ANU Press, The Australian National University, Canberra, Australia. 